\title{
Environmental Quality of Shrimp Ponds in The Coastal Region Of Brebes Regency
}

\author{
Giri Bayuaji ${ }^{1}$, Astrid Damayanti ${ }^{2 *}$, Tuty Handayani ${ }^{2}$ \\ ${ }^{1}$ Bachelor Program of Geography; Faculty of Mathematics and Natural Sciences; Universitas Indonesia; Depok-Indonesia \\ ${ }^{2}$ Department of Geography; Faculty of Mathematics and Natural Sciences; Universitas Indonesia; Depok-Indonesia
}

\begin{abstract}
The largest utilization of coastal areas in Brebes Regency is the shrimp farming ponds. Shrimp volume statistics until 2016 showed that shrimp production in Brebes tends to decrease. The decrease in shrimp production can be caused by disruption in the environmental quality from the surrounding activities. This study aims to analyze the causes of declining production based on the quality of the physical environment of shrimp ponds. The variables used are water quality values ( $\mathrm{Ph}, \mathrm{Tds} / \mathrm{Ec}$, and salino), vegetation values of ponds, and waste disposal values around ponds $(<1000 \mathrm{~m}, 1000-2000 \mathrm{~m},>2000 \mathrm{~m})$. The data used is a Quick Bird image as of 2015 to determine the area of shrimp ponds and results of field survey in February 2018 for water quality sampling and observation. The analytical method that is used is scoring and weighting. The grades of pond environment quality that are produced are Poor; Good; and Well. The results show that the subdistricts of Brebes and Wanasari have well environmental quality; Tanjung has good environmental quality; and environmental value of Bulakamba and Losari subdistricts have poor environmental quality. Environmental quality is strongly influenced by industrial activities, onion farming activities, and settlements. This environmental quality study can be utilized for the management of sustainable shrimp farming.
\end{abstract}

Keywords: shrimp culture, Brebes Regency, environmental quality, coastal, pond.

\section{Introduction}

In the coastal areas of Indonesia coastal land use has been done for various purposes such as agriculture, tourism, and aquaculture [1]. Potential cultivation ponds that are widely developed in the use of coastal areas are the shrimp ponds cultivation [2]. Production of shrimp farming can increase the country's income in the export market competition in the fishery sector [3]. Shrimp farming is growing rapidly when the government establishes shrimp as one of the main commodities in the export market. The policy is in line with the fact that the potential of coastal resources is likely to be large enough for the development of fisheries, both catching and cultivating [5].

In managing shrimp farming, farmers often face problems with rising sea levels that have a big impact on coastal aquaculture activities. Rising water levels inundated coastal areas and destroyed ponds in Java, Kalimantan, and Sulawesi. As a result, shrimp farmers could lose their source of life income [5].

In addition to natural factors, excessive exploitation of aquaculture can also threaten existing shrimp production. Shrimp volume statistic data until 2016 showed that shrimp production in Brebes Regency had fluctuated and tended to decrease [4]. The value of production may depend on the size of the management and operational costs. Environmental factors also have a big impact because the pond land response has been decreasing due to the organic materials that have accumulated up to the approaching saturation point. Here happens what is called the 'law of diminishing return' from cultivated land [6]. Emissions can also affect pond water quality because water particles in the open pool will absorb it. The type and amount of emissions or pollutants depends on the type and number of industries in the region. In general, pollutants from industry and transportation are dust particles and gases. Gas emissions from the air can directly enter the body of water or be carried by rainwater and seep through the soil into the body of water. Exhaust gases containing nitrogen oxides and sulfur oxides (NOx and SOx) can react with water molecules in the air to form sulfuric acid (H2SO4) and nitric acid [7].

In this study, the assessment of the environmental quality of shrimp ponds can improve with the application of the concept of low carbon socitey. Research on the environmental problems of shrimp ponds in Brebes regency can be overcome with the construction of factory areas and residential areas based on low carbon society. With the application of this concept, it can increase air particles with good quality in the atmosphere. The air particles are carried by rainwater which is collected by shrimp ponds. The existence of factories and settlements has no impact on the quality of water for shrimp farming, so that the productivity of shrimp in Brebes Regency is not affected.

* Corresponding author: astrid.damayanti@sci.ui.ac.id 


\section{Materials and methods}

\subsection{Study area}

Brebes Regency is located in the northwest part of Central Java Province, between the coordinates of $108^{\circ} 411^{\prime} 37.7^{\prime \prime}-$ $109^{\circ} 11^{\prime} 28.92^{\prime \prime}$ East Longitude and 6 $6^{\circ} 44^{\prime} 56^{\prime} 5^{\prime \prime}-7^{\circ} 20^{\prime} 51^{\prime} 48$ South Latitude. The area is directly adjacent to the area of West Java Province. The capital of Brebes Regency is located in the eastern part of the regency. Brebes Regency is adjacent to Tegal Regency. The research is located in the coastal area of Brebes Regency which consists of 5 subdistricts: Losari District, Tanjung District, Bulakamba District, Wanasari District and Brebes District.

The sample location is determined from a Quick Bird image as of 2015. The sample size consists of 47 points of pond locations. The distance between the sample locations is approximately $500 \mathrm{~m}$ between one pond and the others.

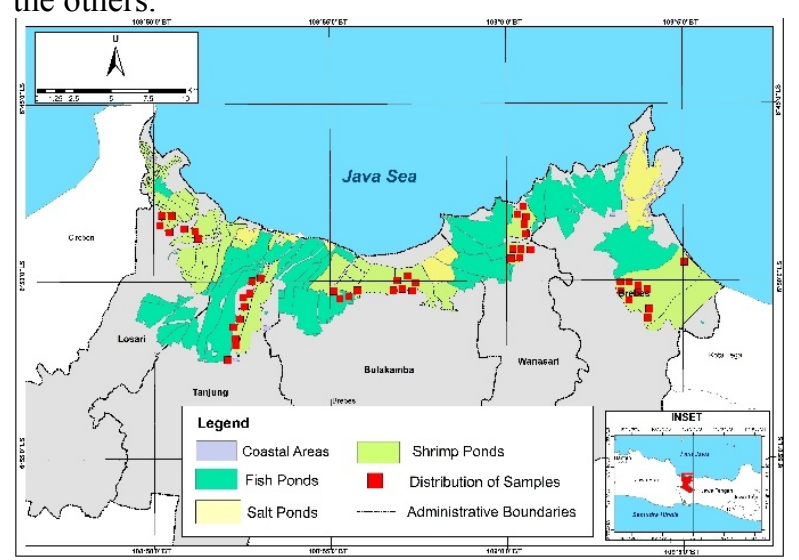

Figure 1. Distribution of Sample Locations of Shrimp Ponds

\subsection{Materials}

This research uses 3 variables including waste around ponds, vegetation, protector around ponds, and pond water quality. Environmental Shrimp Cultivation Management from Bitter management practice of World Wild Fund Indonesia shrimp farming as a good environmental parameter for shrimp farming [9]. The data used to determine the parameters of well, good, and poor environmental value consists of:

1. Vegetation data around the ponds obtained from the observation by the researchers

2. Waste data around the ponds obtained from interviews and observations by the researchers

3. Pool salinity data obtained from interviews with workers or pond owners, direct measurement in the field, and interviews with workers or owners of ponds

4. Data of $\mathrm{pH}, \mathrm{TDS}, \mathrm{EC}$ of pond water obtained from direct measurement result in field.

\subsection{Methods}

Data collection is done by utilizing data from related agencies and in situ measurement of environmental parameters to obtain environmental quality data. The production data of each subdistrict was obtained from the
Directorate General of Brebes Aquaculture while the environmental parameters were measured in February 2018 .

The processing of shrimp pond's environmental value data uses salinity, $\mathrm{pH}$, vegetation, and waste parameters. The environmental data obtained were then weighted: Water quality $(50 \%)$, vegetation $(25 \%)$, and waste $(25 \%)$ and environmental quality scoring: poor (1), good (2), and well (3). Determining the environmental values is obtained by related literature [9].

After categorizing in table 1 , it can be seen that the environmental quality parameters have a weighting value which is either: Poor (Final Score: 4-6), Good (Final Score 7-9), or Well (Final Score 10-12). The results which will be obtained later are calculations from final score average in each district which then become the object of research.

Table 1. Parameters of Environmental Quality of Shrimp Ponds

\begin{tabular}{|c|c|c|c|}
\hline \multicolumn{4}{|c|}{ Vegetation } \\
\hline Category & Score & Weight & Class \\
\hline Has a vegetation & 1 & & Poor \\
\hline $\begin{array}{l}\text { Has no vegetation and no } \\
\text { protectors }\end{array}$ & 2 & $\begin{array}{l}25 \% \\
(\mathrm{x} 1)\end{array}$ & Good \\
\hline $\begin{array}{l}\text { Has a vegetation and a } \\
\text { protector }\end{array}$ & 3 & & Well \\
\hline \multicolumn{4}{|c|}{ Water Quality } \\
\hline Category & Score & Weight & Class \\
\hline $\begin{array}{c}\text { Ph: }>8.5 ; \text { Tds } / \text { Ec: }>500 \mathrm{ppm} ; \\
\text { Salinity: }>30 \mathrm{ppt}\end{array}$ & 1 & & Poor \\
\hline $\begin{array}{c}\text { Ph: } 7.0-7.5 ; \text { Tds/Ec: } 100-250 \\
\text { ppm; } \\
\text { Salinity: } 0-15 \text { ppt }\end{array}$ & 2 & $\begin{array}{l}50 \% \\
(\mathrm{x} 2)\end{array}$ & Good \\
\hline $\begin{array}{c}\text { Ph: } 7.5-8.5 ; \text { Tds/Ec: } 250-500 \\
\text { ppm; } \\
\text { Salinity: } 15-30 \mathrm{ppt}\end{array}$ & 3 & & Well \\
\hline \multicolumn{4}{|c|}{ Distance From Waste } \\
\hline Category & Score & Weight & Class \\
\hline$<1000$ meters & 1 & & Poor \\
\hline $1000-2000$ meters & 2 & $\begin{array}{l}25 \% \\
\text { (x } 1)\end{array}$ & Good \\
\hline$>2000$ meters & 3 & & Well \\
\hline
\end{tabular}

\section{Results and discussion}

\subsection{Production of Shrimp in Brebes Regency}

Brebes Regency is the center of shrimp farming. The shrimp pond area covers 14 ha of intensive shrimp farming and 403 ha of extensive shrimp farming. Shrimp production is one of the important factors in determining the growth of fishery economy. Production is a source of growth in fishery commodities whose production increases significantly such as fish / shrimp [10] 
Figure 2. Total Production and Value of Brebes Shrimp Production in 2017 [11]

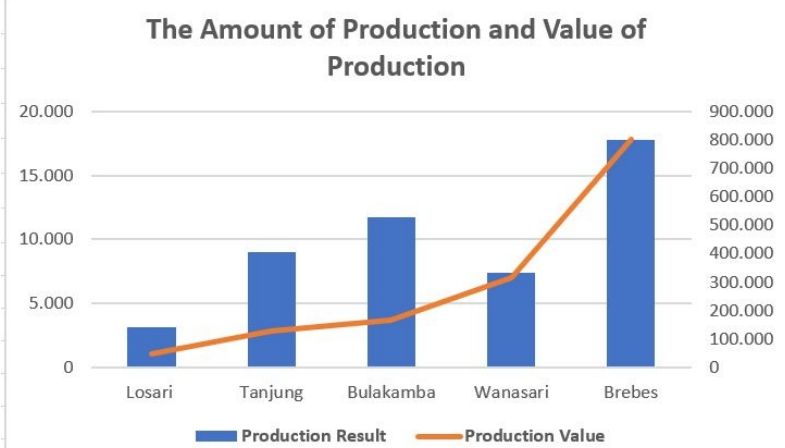

Fig 2 shows that there is a difference in shrimp production in Brebes Regency in 2017. Shrimp production data in Brebes Regency in 2017 amounted to $49,065 \mathrm{~kg}$ with production value of Rp1,455,210,000. [11]. Differences in production results are influenced by the extent of different ponds in each subdistrict. Can be seen in Fig 3, Losari District with 1,008 ha wide which has a shrimp production amount of $3,150 \mathrm{~kg}$ and production value equal to $\mathrm{Rp} 45,600,000$. With the extension of 1,035 ha of Tanjung District has $7,400 \mathrm{~kg}$ of production and production value Rp129,180,000. In Bulakamba District with shrimp pond area of 1,105 ha has a production amount of $11,745 \mathrm{~kg}$ with a production value of Rp164,430,000. In Wanasari District with a pond area of 1090 ha has a production value of $8,970 \mathrm{~kg}$ with a production value of Rp315,000,000. In Brebes District with 1,503 pond area has a production amount of 17,800 $\mathrm{kg}$ with production value of $\mathrm{Rp} 801,000,000$. [12]

\subsection{Environmental Quality of Shrimp Pond}

The quality of the environment around the pond can affect the existing shrimp production. Environmental factors affecting shrimp production, in this case, are influenced by 3 factors, namely wastes around the pond, vegetation type and protection around the pond, and pond water quality [13]. One of the concerns is the water quality for the shrimp farming source. All human activities around the shrimp farms can affect the quality of nearby shrimp farms.

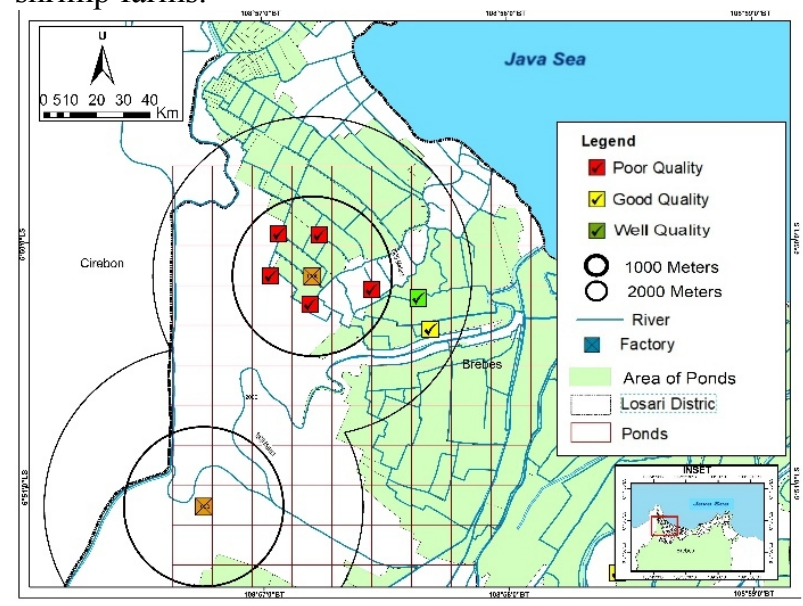

Figure 3. Environmental Quality of Losari Shrimp Ponds
Losari District is a district with poor environmental quality of shrimp farming, with a score of 1 and a percentage of $57 \%$. In Fig 3, it can be seen that the value of environmental quality in the Losari District is influenced by the pattern of shrimp pond distribution which approaches the factory radially. The pattern affects the water quality received by shrimp farmers because the water flow has been contaminated by factory waste. Tanjung District is a subdistrict with good environmental quality of shrimp pond, with a score of 2 and a percentage of $40 \%$.

The closer distance from industrial activity can reduce changes in chemical levels in water. Increased changes in chemical levels in water occur due to chemical accumulation in the river, so the location of shrimp ponds with a distance of $<1000 \mathrm{~m}$ has poor quality. The decrease in changes in chemical levels in water occurs due to chemical deposition at the bottom of the river because the $\mathrm{pH}$ value of water is influenced by the value of DHL water, the location of shrimp ponds with a distance of $>$ $2000 \mathrm{~m}$ has good quality and is very good

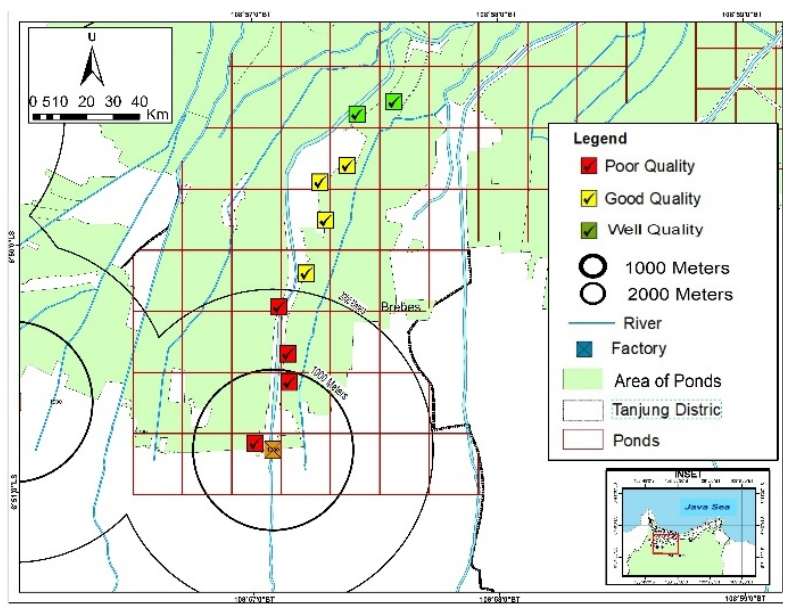

Figure 4. Environmental Quality of Tanjung Shrimp Ponds

The shrimp pond distribution pattern in Tanjung District follows the Pemali River to the estuary, but the existence of the factory in the upstream part effects the environmental quality nearby. In Fig 4, it can be seen that the shrimp farms in the south tend to have worse quality, but gradually improves to the north. This indicates that the distance from industrial activity effects the quality of the environment.

Pesticides used on shallot farming land, especially at the beginning of the growing season, some or even all will fall and enter the water so that it pollutes the waters. Pond waters and irrigation channels in Brebes Regency, Central Java were contaminated by endosulfan insecticides derived from agricultural and plantation wastes with concentrations of 2.7 and $3.2 \mu \mathrm{g} / \mathrm{L}$ respectively. Waters that are polluted by pesticide residues when they have reached a certain concentration will greatly affect the environment and aquatic organisms that live in them [14]. Fish that live in aquatic environments contaminated with pesticides will absorb the active ingredients of these pesticides and stored in the body, because fish are good 
accumulators for various types of pesticides, especially those that are lipophilic (easily bound in fat tissue).

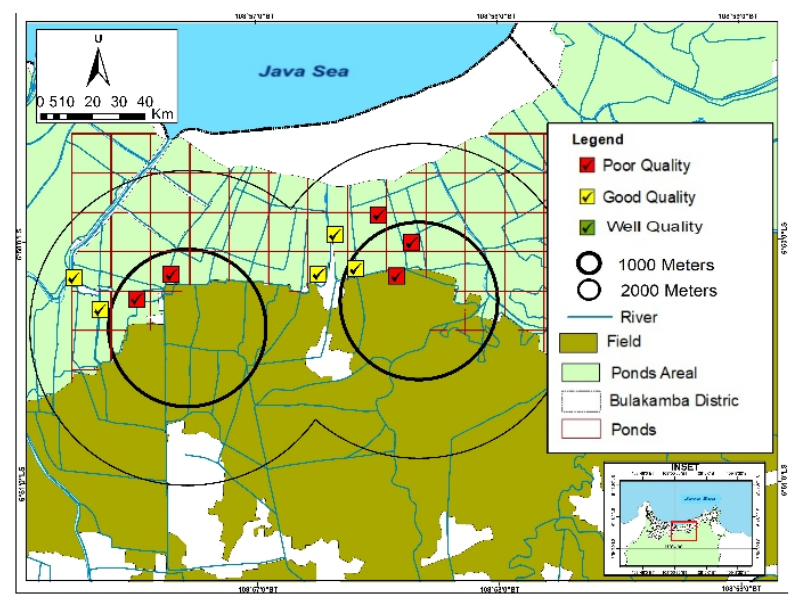

Figure 5. Environmental Quality of Bulakamba Shrimp Ponds

Bulakamba District is a subdistrict with poor environmental quality of shrimp farming, with a score of 1 and a percentage of 50\%. In Fig 5, it can be seen that the influence of shrimp pond distance with the field affect the quality of the environment. The quality of the environment is influenced by the water flow that leads to downstream after being used first by farmers at the upstream part.

The location of shrimp farms in Wanasari subdistrict with a distance adjacent to the settlements gets poor quality values, because the household waste of the surrounding communities flows downstream through the same river flow that is utilized by shrimp farmers. From observations, water quality contamination can be reduced by a distance of $>2000 \mathrm{~m}$, so that it can be seen in figure 6 that the location of the pond has good quality and is very good in the area $>2000 \mathrm{~m}$

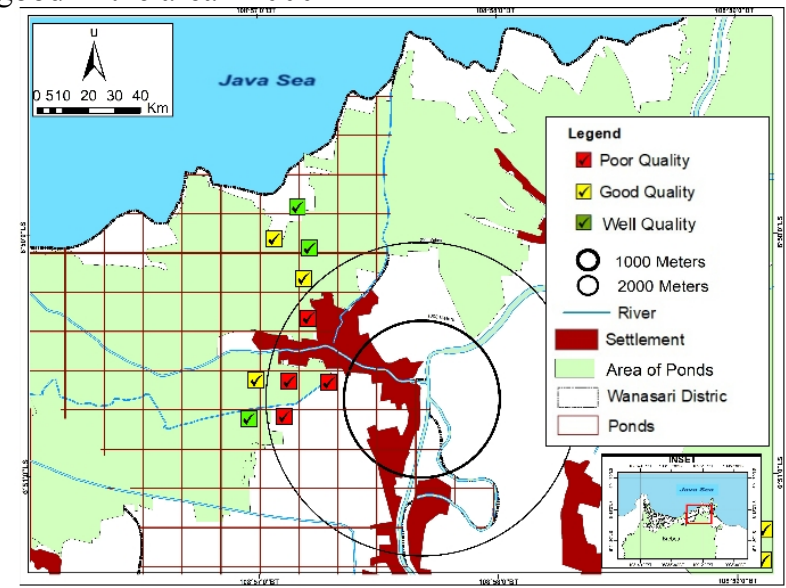

Figure 6. Environmental Quality of Wanasari Shrimp Ponds

Wanasari District is a subdistrict with good environmental quality of shrimp farming, with a score of 2 with a percentage of $30 \%$. In Fig 6 , it can be seen that the environmental quality of shrimp pond quality is below well within a distance of $1000 \mathrm{~m}$ to the settlement. The river flow used by farmers has already been polluted by household waste which is near the pond.
Environmental problems in Brebes sub-district are the same problems as Wanasari sub-district, the location of shrimp ponds is too close to the settlement. The river flow used by shrimp farmers is only 1 , namely the Brebes river in the downstream, but the river has been used first by the community in the upstream

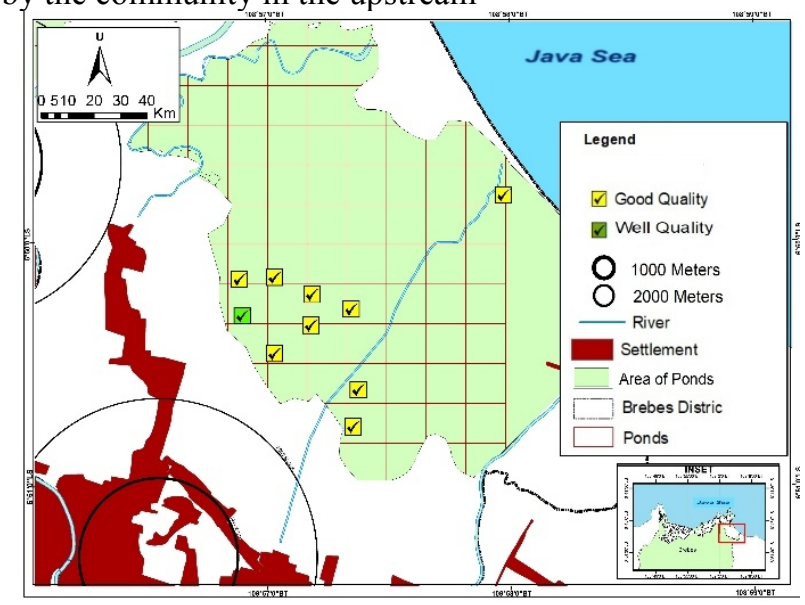

Figure 7. Environmental Quality of Brebes Shrimp Ponds

Handling proper environmental problems has been done by shrimp farmers in Brebes sub-district, can be seen in figure 7 has a good and very good environmental quality value, this is because there is an environmental boost from its management. Shrimp farms in Brebes subdistrict are pilot shrimp farms by applying intensive cultivation, so as to minimize the adverse effects of the river flow affected by household waste in the southern region.

Brebes District is a subdistrict with good environmental quality of shrimp farming, with a score of 2 and a percentage of $90 \%$. In fig 7, we can see the value of environmental quality of shrimp ponds in Brebes District. The effect of distance on shrimp farms can be minimized because the distance is $>2000 \mathrm{~m}$. The percentage of shrimp pond environmental quality in Brebes Regency that are in the parameters of poor, good, and well is the environmental quality that are determined by the condition of surrounding environment. The location should not be near pollution sources such as factories, onion fields, and residential areas.

Table 2. Environmental Quality of Shrimp Ponds

\begin{tabular}{|l|c|c|c|c|}
\hline District & $\begin{array}{c}\text { Poor } \\
(\%)\end{array}$ & $\begin{array}{c}\text { Good } \\
(\%)\end{array}$ & $\begin{array}{c}\text { Well } \\
(\%)\end{array}$ & $\begin{array}{c}\text { Total Of } \\
\text { Percentage } \\
(\%)\end{array}$ \\
\hline Losari & 8,5 & 4,3 & 2,1 & 14,9 \\
\hline Tanjung & 8,5 & 8,5 & 4,3 & 21,3 \\
\hline Bulakamba & 10,6 & 10,6 & 0,0 & 21,3 \\
\hline Wanasari & 8,5 & 6,4 & 6,4 & 21,3 \\
\hline Brebes & 0,0 & 19,1 & 2,1 & 21,3 \\
\hline Total & 36,2 & 48,9 & 14,9 & 100,0 \\
\hline
\end{tabular}

Table 2 shows the total value of environmental quality of shrimp ponds in Brebes Regency which are classified as poor as much as $36,2 \%$, in good classification as much 
as $48,9 \%$, and in well classification as much as $14,9 \%$. Table 2 also shows subdistricts with poor environment quality of shrimp farming in Bulakamba District with a value of $10.6 \%$. Shrimp ponds with good environmental quality is located in Brebes District with a value of $19,1 \%$. Shrimp ponds with well environmental quality is located in Wanasari District with a value of $6,4 \%$. The source of pollution around the pond becomes the trigger of the environmental condition of shrimp pond.

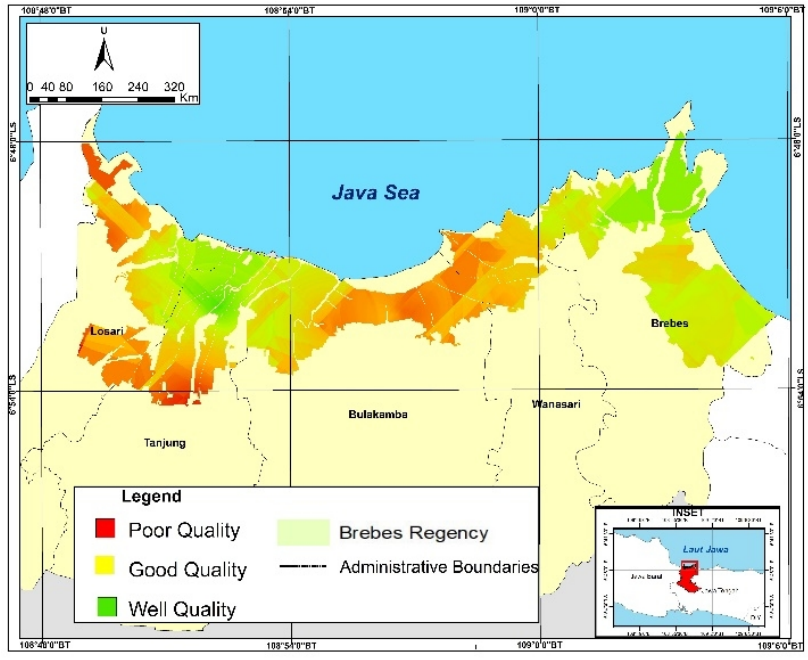

Figure 8. Environmental Quality of Brebes Shrimp Ponds

Fig 8 shows that the environmental quality of shrimp ponds in Brebes Regency has poor quality in the southern part of Tanjung District and the northern part of Losari District. The poor quality is also found in the eastern Bulakamba District. Losari District and Brebes District on Fig 8 shows the environmental quality of shrimp pond is good to very good. The environmental quality of shrimp ponds in Brebes Regency will affect shrimp production if the cultivation is not managed well. Areas that have poor quality requires more intensive management than areas with good environmental quality. When the cultivation management is done maximally, the shrimp farming production level will increase.

\section{Conclusion}

The biggest influence of environmental quality in Bulakamba sub-district with a value of $10.6 \%$ of agricultural activities at a distance of $<1000 \mathrm{~m}$ from shrimp ponds affects the water quality of ponds. the use of pesticides on shallot plants is thought to be the cause of the poor environmental quality of shrimp ponds in Bulakamba district.

Meanwhile, the pattern of shrimp pond distribution in Losari District is formed by the influence of the processed products factory at its center. These industrial activities can cause poor environmental quality for shrimp farms.

Thanks are due to Directorate of Research and Community Service (DRPM) Universitas Indonesia that has supported this research in form Hibah PITTA with contract number of 2236/UN2.R3.1/HKP.05.00/2018.

\section{References}

1. Barti. Analisis Teknik Usaha Budidaya Udang Vaname (Litopenaeus Vannamei Boone, 1931) Dalam Tambak Pada Lahan Pasir Di Pesisir Kecamatan Galur Kabupaten Kulon Progo (2017).

2. Nurjanah. Analisis Prospek Budidaya Tambak di Kabupaten Brebes, Semarang. Program Pasca Sarjana UNDIP 1-71 (2006).

3. Diah D. Analisis Daya Saing Ikan Tuna Indonesia di Pasar Internasional. Malang :Universitas Muhammadiyah Malang (2016).

4. Karim, Muhammad. Perubahan Iklim Global Ancam Perikanan Kita, Sinar Harapan, 10 Februari 2009.

5. Kisworo, Y. Analisis Usaha budidaya Tambak Udang Dengan Pendekatan Tata Ruang Wilayah Pada Kawasan Pengembangan Wilayah Terpadu Batu Licin di Kabupaten Tanah Bumbu Provinsi Kalimantan Selatan. Tanah Bumbu: Universitas Stuttgart (2007).

6. Lilis Imamah I.,S. Hartoyo, Y. Syaukat, dan S. Utami K. Total Faktor Produktivitas Usaha Tambak Terkait dengan Polutan Tambak di Kabupaten Karawang: Jurnal Agribisnis, Vol. 7, No. 1. (Juni 2013)

7. Iryani, Ani. Pengaruh Pencemaran Udara Terhadap Kualitas Air Sumur: (Studi Kasus: Air sumur penduduk wilayah industri Cibinong-Citerup-Gunung Putri,Kabupaten Bogor, Jawa-Barat)

8. Karim, Muhammad. Perubahan Iklim Global Ancam Perikanan Kita, Sinar Harapan, 10 Februari 2009.

9. World Wildlife Fund Indonesia. Better Management Practice Budidaya Udang Vannamei. Jakarta: WWF Indonesia (2014).

10. Asche, F., K.H. Roll, and R. Tveteras. Productivity Growth in the Supply Chain-Another Source of Competitiveness for Aquaculture. Marine Resource Economics, 22:329-334. (2007).

11. Dinas Kelautan dan Perikanan (DKP) Brebes. Data Produksi Udang di Kabupaten Brebes. Jakarta: KKP Pusat (2009).

12. Direktorat Jendral Perikanan Budidaya (DJPB). KKP. Data Komuditas Utama Kabupaten Brebes Tahun 2017. Brebes: KKP Kabupaten Brebes.

13. Haliman, R.W. dan Adijaya, D. Udang Vannamei. Jakarta: Penebar Swadaya (2005).

14. Taufik, I., Koesoemadinata, S., Sutrisno, \& Nugraha, A. 2003. Tingkat akumulasi residu pestisida pertanian di perairan tambak. J. Pen. Perik. Indonesia, 9(4): 5361 . 